International Business Management 13 (9): 392-396, 2019

ISSN: 1993-5250

(C) Medwell Journals, 2019

\title{
Determinants of Banks Profitability in a Developing Economy: Empirical Evidence from Palestine
}

\author{
Khaled Abdallah Zidan \\ Department of Banking and Finance, Faculty of Economics and Social Studies, \\ An-Najah National University, Nablus, Palestine
}

\begin{abstract}
This study analyzes bank-specific, industry-specific and macroeconomic determinants that affect bank profitability. Dynamic panel analysis is applied on the sample of 14 banks in the Palestinian banking system in the period between 2008 and 2018. Regression model was used to do the empirical analysis and develop the econometric model consisted of one dependent variable and nine independent variables. According to the obtained results, among bank-specific factors of bank profitability, the most important one is operating expense management. Regarding the external variables, economic growth show significant effect on bank profitability in Palestine.
\end{abstract}

Key words: Determinants of profitability, Palestine banking sector, macroeconomic, industry specific, management

\section{INTRODUCTION}

Efficient financial system should have solid and robust intermediation process is in fact a revenue-generating activity for most banks, show profitability improvements and better quality services for consumers (Sufian and Habibullah, 2009). According to the theoretical and empirical works bank profitability is determined by various firm specific, industry specific and macroeconomic factors which requires studying and analyzing these factors and determining their importance in influencing profits. The increased competition among financial firms, after the liberalization of trade in services as well as compliance with Basel requirements, challenges and risks facing the banking sector have grown which may lead to insolvency of the bank as a result of a temporary shortfall in liquidity, poor risk management and unplanned expansion in some operations (Atikogullari, 2009). Despite the importance of the banking sector and its remarkable development in recent years, still the identification and analyses of the bank profitability determinants, knowing the factors and variables that affect profits has a huge matter, especially, in this competitive environment. Furthermore, identifying the profitability determinants is important to the bank's owner as well the regulatory maker as they can assess and adjusts the performance of banks and regulation to maximize profit.

Aims, questions and hypothesis

Research objectives: The main aim of this study was to find out and identify the factors affecting the profitability of banks operating in Palestine.
Address the causes that lead to losses or reduce their profitability and going out with recommendations would preserve the profits of banks, improve profitability and address the causes that lead to losses or reduce their profitability.

Research questions: Despite the importance of the banking sector and its remarkable development in recent years, still the identification and analyses of the bank profitability determinants, knowing the variables that affect profits has a huge matter, especially, in this competitive environment. Furthermore, identifying the profitability determinants is important to the bank's owner as well the regulatory maker as they can assess and adjusts the performance of banks and regulation to maximize profit. Against this background and problem formulation, the major research question is the following: what are the most important factors and variables that affect the profitability of banks operate in Palestine?

Research hypothesis: In the light of the research objectives, the researcher sought to test the following hypotheses:

- $\mathrm{H}_{1}$ : Asset Size (AS) has a positive impact on bank's profitability

- $\mathrm{H}_{2}$ : Asset's structure (LAT) has a positive impact on bank's profitability

- $\mathrm{H}_{3}$ : Asset's quality (LLP) has a positive impact on bank's profitability

- $\mathrm{H}_{4}$ : Capital Adequacy (CAR) has a positive impact on bank's profitability

- $\mathrm{H}_{5}$ : Liquidity (LTD) has a negative impact on bank's profitability 
- $\mathrm{H}_{6}$ : operating expense management (CIR) has a positive impact on bank's profitability

- $\mathrm{H}_{7}$ : Activity Mix (AM) has a positive impact on bank's profitability

- $\mathrm{H}_{8}$ : Market Share (MS) has a positive impact on bank's profitability

- $\mathrm{H}_{9}$ : Economic Growth (EG) has a positive impact on bank's profitability

\section{Literature review}

Theoretical and conceptual framework: According to the theoretical and empirical works, bank profitability is determined by various firm specific, industry-specific and macroeconomic variables. First, there is a group of determinants of profitability that are specific to each bank and that in many cases are the direct result of managerial decisions (asset structure, asset quality, capitalization, cost efficiency, size and income diversification). The second group of determinants includes factors relating profitability to the industry structure and to the macroeconomic environment within which the banking system operates such as industry concentration and economic growth. This section explores the previous literature related to the scope of this research and the determinants suggested by several studies in which conducted locally and globally, regarding the profitability of banks.

Overview of the Palestinian banking sector: The banking sector has great impact on the Palestinian economy as it is the main funding channel for the private and public sector and the main source of credit in the local market due to the capital market weakness and limitation and the lack of the ability to provide adequate sources of financing to investors.

The Palestinian banking sector consists of domestic and foreign banks. Fourteen banks operate in Palestine, seven of them are domestic (three of them are Islamic) and the rest are foreign with a total of 343 branches and offices. The banking sector has total assets reaching USD 16.125 billion, deposits of US\$ 12 billion and credit facilities of US\$8 billion at the end of year 2018 .

Determinants of bank profitability: There are various factors affecting the profitability of banks. Generally, these factors are categorized as bank specific, industry specific and macroeconomic factors. Bank specific factors such bank size, asset quality, capital adequacy, liquidity and overhead expense management. These variables within the control of the bank and which are mainly influenced by the bank's management decisions. Industry-specific determinants demonstrate industry conditions such concentration, ownership and market share. Macroeconomic factors such as inflation, GDP and market capitalization reflect the economic environment where banks operate and management has no control over.
Bank-specific profitability determinants; asset's size: Asset size is the total market value of the securities in the bank's portfolio. It can also be referred to assets under management. The asset's size of a bank can be important for investors to consider for a few reasons. Firstly, the greater the asset's size the more trust the investors have in the bank's management. Secondly, larger assets size tends to be more actively traded in the market with higher average daily trading volume providing for greater market liquidity.

Asset's structure: Assets are mainly composed of liquid assets and profitable assets in which liquid assets are kept for meeting customer's withdrawal demands which generates faith and credibility to the public. On the other hand, profitable assets are used to make reasonable profit by operating and investing the customer's deposits as loan and long-term loans. Thus, banks should keep a balanced assets structure; a combination of both types of assets.

Asset's quality: The asset's quality ratio reflects the amount of existing and potential credit risk associated with loans. Furthermore, the evaluation of asset quality should consider the adequacy of the allowance for loan losses. Assets quality is an important factor to investors because it's one of the main sources of the bank's earnings.

Capital adequacy: Capital adequacy refers to the sufficiency of the amount of equity to absorb any shocks that the bank may experience. Capital adequacy is a measure of the financial strength of a bank; it is commonly expressed as capital to its assets ratio.

Several ratios can be used for measuring capital adequacy. The researcher chose the ratio of total shareholder's equity/net assets. This has been used as an indicator of capital adequacy.

Liquidity: Liquidity risk reflects the probability of bank inability to meet its obligations which can eventually lead to bank failure even though, technically, it may still be solvent. The exposure to liquidity risk is usually measured by many ratios as ratio of loans to deposits and cash assets and government securities to total assets (Kosmidou et al., 2004). In order to reduce the insolvency problems, bank holds the right amount of immediately spendable funds when they are required and its ability to raise liquidity at timely fashion. However, liquid assets usually have lower rates of return. Therefore, higher liquidity would imply lower profitability.

Operational expense management: CIR can be defined as the ratio between the business non-interest expenses and its net interest and commission income. With this ratio, the bank can see how much of its interest and commission income is spent on various expenses not including interest expense. By calculating this ratio, the 
bank can manage the amount of non-interest expenses they have and generate strategies to reduce it to have a lower ratio, meaning fewer expenses are being spent and more income is preserved.

Activity mix: The bank activity mix is also an important proxy for the overall level of risk undertaken by banks to the extent that different sources of income are characterized by different credit risk. A bank's activity mix is represented by the share of non-interest income in the form of fees, commissions and trading income to its total revenues. The activity mix comes from the wide range of financial activities that banks offer.

Industry-specific profitability determinants; market share: Market share is a firm's percentage of an industry's total sales. It is calculated as total assets of the bank as a percentage from total assets of the whole system. Market share is usually used to express competitive position used as the proxy for market power.

Macroeconomic profitability determinants; economic growth: Bad economic conditions can worsen the quality of the loan portfolio; generating credit losses and increasing the provisions banks need to hold, thus, reducing bank profitability. In contrast, an improvement in economic conditions in addition to improving the solvency of borrowers, increases demand for credit by households and firms with positive effects on the profitability of banks (Athanasoglou et al., 2008).

\section{MATERIALS AND METHODS}

For achieving the aim and objectives, the study was based on the descriptive method in order to identify the most important factors and variables that affect the profitability of banks operate in Palestine.
Study population: Palestinian banking sector has been chosen for conducting this study which comprised from fifteen banks commercial and islamic from 2008 until 2018. The necessary data were collected from each bank's annual audited financial statements, the association of banks in Palestine and from Palestinian Monetary Authority (PMA)'s annual reports. In the light of the elements and the dimensions of the problem, the researcher built a study model on the basis of the relationship between the independent variables of banking sector (expressed in terms of the asset's size, asset's structure, asset's quality, capital adequacy, liquidity, operating expense management, activity mix, market share and economic growth) and the dependent variable (Return on Assets) (Table 1).

Data collection: The study data has been collected from sampled banks annual reports which is mainly represented in the financial statements of the banks (2008-2017) and published annual financial reports and its notes as well as the statistics issued by the Palestinian Monetary Authority (PMA). Also, for theoretical background of this study and its literature review, books and academic papers published on the subject of this current study were collected from libraries, relevant websites and available database to cover this part of the study.

Model of the study: Based on the light of the elements and the dimensions of the problem the researcher employed the regression model presented below to highlight the relationship between the independent variables on the one hand and the dependent variables (ROA) on the other hand. The following mathematical equations illustrate the model (Table 2):

$$
\begin{aligned}
& \mathrm{ROA}=\alpha+\beta 1(\mathrm{AS})+\beta 2(\mathrm{LAT})+\beta 3(\mathrm{LLP})+\beta 4(\mathrm{CAR})+\beta 5(\mathrm{LTD})+ \\
& \beta 6(\mathrm{CIR})+\beta 7(\mathrm{AM})+\beta 8(\mathrm{MS})+\beta 9(\mathrm{EG})+\varepsilon
\end{aligned}
$$

\begin{tabular}{|c|c|c|c|c|c|}
\hline Bank & Total assets & Total equity & Total revenue & Customer deposits & Net loans \\
\hline Bank of Palestine & $1,286,036.545$ & $449,961.687$ & $220,934.607$ & $3,768,631.790$ & $2,518,590.540$ \\
\hline Arab Islamic Bank & $1,041,103.696$ & $106,995.915$ & $33,905.595$ & $790,906.601$ & $560,923.314$ \\
\hline Palestine Islamic Bank & $1,010,369.417$ & $109,625.653$ & $51,483.551$ & $809,630.033$ & $619,378.328$ \\
\hline Palestine Investment Bank & $443,291.111$ & $90,899.358$ & $19,253.947$ & $297,663.960$ & $210,578.198$ \\
\hline Al Quds Bank & $1,075,629.534$ & $102,730.674$ & $53,678.398$ & $855,348.926$ & $658,517.963$ \\
\hline The National Bank & $1,097,399.362$ & $97,567.177$ & $39,655.177$ & $808,784.822$ & $653,847.526$ \\
\hline Arab Bank & $3,547,941.320$ & $296,020.440$ & $163,140.161$ & $3,022,899.717$ & $1,784,676.441$ \\
\hline Cairo Amman Bank & $971,247.128$ & $103,698.942$ & $39,956.911$ & $718,627.032$ & $484,585.223$ \\
\hline Bank of Jordan & $624,428.031$ & $93,459.150$ & $26,962.628$ & $515,293.186$ & $278,444.475$ \\
\hline Housing Bank & $645,348.587$ & $99,190.300$ & $26,756.075$ & $521,282.010$ & $208,358.488$ \\
\hline Egyptian Arab Land Bank & $170,651.353$ & $44,890.975$ & $6,103.100$ & $102,253.911$ & $105,116.988$ \\
\hline Jordan Ahli Bank & $411,958.896$ & $83,898.798$ & $18,626.159$ & $299,040.866$ & $198,784.700$ \\
\hline Commercial Bank of Jordan & $243,997.773$ & $59,692.117$ & $8,865.454$ & $135,384.701$ & $105,166.913$ \\
\hline Jordan Kuwait Bank & $139,801.616$ & $50,935.221$ & $2,834.808$ & $67,257.401$ & $21,496.172$ \\
\hline
\end{tabular}

Table 1: Selected data for the sample banks for the year 2017 in USD millions 
Int. Business Manage., 13 (9): 392-396, 2019

Table 2: Description of variables in the model

\begin{tabular}{|c|c|}
\hline Variable & Formula \\
\hline \multicolumn{2}{|l|}{ Dependent variables $Y$} \\
\hline Bank profitability: & Return on Assets (ROA) \\
\hline \multicolumn{2}{|l|}{ Independent variables } \\
\hline Asset’s Size (AS) & Log of total asset \\
\hline Asset's structure (LAT) & Total loans/total assets \\
\hline Asset’s quality (LLP) & Loan Loss Provisions/total loans \\
\hline Capital Adequacy Ratio (CAR) & Total equity/total assets \\
\hline Liquidity (LTD) & Total loans/total deposits \\
\hline $\begin{array}{l}\text { Operating expense } \\
\text { management (CIR) }\end{array}$ & $\begin{array}{l}\text { Non-interest expense (total expense/ } \\
\text { total revenue) }\end{array}$ \\
\hline Activity Mix (AM) & $\begin{array}{l}\text { Total revenue-interest income/total } \\
\text { revenue }\end{array}$ \\
\hline Market Share (MS) & $\begin{array}{l}\text { Total assets of the bank/total assets of } \\
\text { the whole system in the year } t\end{array}$ \\
\hline Economic Growth (EG) & $\begin{array}{l}\text { Real Growth Domestic Product } \\
\text { (RGDP) }\end{array}$ \\
\hline
\end{tabular}

\section{RESULTS AND DISCUSSION}

One of the functions of linear regression that examines the strength of the relationship between independent variables and dependent variable. In addition to that it works on framing this relationship in a mathematical model used for prediction (Table 3).

Table 3 presents regression results for the profitability equation for the model where ROA is dependent variable. It showed that Asset Size (AS) has positive insignificant impact on ROA, thereby, it has little impact on profitability. The positive insignificant relationship, indicating that the more banks assets and investments the more profitable they become. This finding is consistent with the research hypothesis. The insignificance of bank size is also found by Goddard et al. (2004); Haron (2004); Khan (2012); Zeitun and Tian (2007). The table also shows that asset's structure (LAT) has a positive significant impact on ROA, indicating that the more banks hold income generating assets, especially, loans the more profitable they become. The result is consistent with the research hypothesis and previous findings of Yang and Chan (2010).

The results also showed that asset's quality (LLP) affected ROA negatively. Since, LLP ratio was negative but insignificant. It is clear that there was a negative relationship between poor asset quality and profitability. CAR has negative significant impact on ROA, indicating that the negative relationship was due to the volume of negative reserves of banks which produce poor profitability results, furthermore, this negative relationship also attributes to the weak capital base by most of commercial in the study sample. The result is not consistent with the research hypothesis and previous findings of Bikker and $\mathrm{Hu}$ (2002) and Goddard et al. (2004).
Table 3: Descriptive statistics for regression variable Dependent variable: ROA

Method: Panel EGLS (cross-section random effects) Sample: 2008-2018

Cross-sections included: 14

Total panel (balanced) observations: 154

\begin{tabular}{lllll}
\hline Variable & Coefficient & SE & t-statistic & Prob. \\
\hline C & 0.0918139 & 0.035865 & 2.560705 & 0.0134 \\
LOG Asset's size & 0.003009 & 0.001766 & -1.703797 & 0.0945 \\
Asset's structure & 0.001119 & 0.013734 & -0.081468 & 0.0254 \\
Asset's quality & -0.083499 & 0.080082 & -1.042665 & 0.3020 \\
Capital adequacy & -0.005667 & 0.002147 & -2.639939 & 0.0110 \\
Liquidity & -0.006495 & 0.014335 & -0.453001 & 0.6525 \\
Operating expense & -0.022755 & 0.002073 & -10.97666 & 0.0000 \\
management & & & & \\
Activity mix & 0.000319 & 0.003972 & 0.080225 & 0.3964 \\
Market share & 0.030899 & 0.016929 & 1.825761 & 0.0737 \\
Economic growth & 0.030999 & 0.001897 & 0.0987431 & 0.0123 \\
Effect specification & & & SD & Rho \\
Cross-section random & & & 0.001634 & 0.2214 \\
Idiosyncratic random & & & 0.003064 & 0.7786 \\
Weighted statistics & & & & \\
$R^{2}$ & 0.612356 & & & \\
Adjusted R ${ }^{2}$ & 0.587685 & \multicolumn{2}{|c}{} & \\
F statistic & 36.58867 & Durbin- & 2.274962 & \\
& & Watson stat & & \\
Prop (F-statistic) & 0.000000 & & &
\end{tabular}

LTD (the ratio that measures liquidity) affected ROA negatively. Since, LTD ratio was negative but insignificant. It is clear that there was a negative relationship between liquidity and profitability because Palestinians banks comprise more income generating assets than liquid assets in their investment portfolio. The result is consistent with the research hypothesis and previous findings of Albertazzi and Gambacorta (2010).

The results also showed that a negative change in operating expense management will have a positive impact on ROA. A major contributor to insufficient level of profitability is a weak or poor expense management. As it is expected it shows negative sign. Operating expenses could be affected by level of the productivity (the low levels of productivity and high levels of inefficiency) in the Palestinian banking sector. Further, newly established banks have high costs in the first years of their business, since, most of banks operate in Palestine are newly established. Namely, they are mainly focused on increasing their market share that would results in higher expenses. Thus, the banks should focus more on management of these expenses. As the result, the improved efficiency will increase bank profitability. The result is consistent with the research hypothesis and previous findings of Berger et al. (2000) and Khan (2012).

As we expected, Activity Mix (AM) was positive. However, it is insignificant. Thus, bank non-credit activities are not at the level of importance in the Palestinian banking sector at which they influence the bank profitability. According to the Palestinian Monetary 
Authority (PMA) reports, almost $13 \%$ of banks income is from non-credit activities. The result is consistent with the research hypothesis and previous findings of Meslier et al. (2014).

Bank's Market Share (MS) has insignificant positive effect on bank's profitability which indicate, the larger the market share of a bank, the higher the profitability earned by the bank. As it mentioned before, the increased number of bank branches do not necessarily increased profitability if it has high fixed and operational costs which needs to be managed and controlled well. The result is consistent with the research hypothesis and with the Berger who found the positive effect of the market share on bank efficiency.

As it is expected, Economic Growth (EG) positively and significantly affects bank profitability. Favorable economic conditions in the terms of growing economic activities, means increasing of household savings and demand for financing. The result is consistent with the research hypothesis.

\section{CONCLUSION}

This study analyzed bank-specific, industry-specific and macroeconomic determinants that affect bank profitability. Dynamic panel analysis is applied on the sample of 15 banks in the Palestinian banking system in the period between 2008 and 2018. Since, the internal determinants are controlled and influenced by management decisions, banks have means to influence them. The most important bank-specific determinant of bank profitability is operating expense management. Thus, there is need to undertake the activities that reducing administrative and personnel costs and in that way improvement of the cost efficiency. Among other internal factors affecting profitability is the asset structure variable, indicating that the more banks hold income generating assets, especially, loans the more profitable they become. Thus, there is need to undertake more investments in credit activities, since, loans to deposit ratio in Palestine (65\%) still low compared to the countries in the region. Also banks need to involve more in productive investments and not to be conservative in their investments which results in sustainable growth. Also there is a need to increase and diversify fee-based services and to generate new source of income. Regarding external variables, beside of market share GDP growth has the highest importance.

\section{REFERENCES}

Albertazzi, U. and L. Gambacorta, 2010. Bank profitability and taxation. J. Banking Finance, 34: 2801-2810.

Athanasoglou, P.P., S.N. Brissimis and M.D. Delis, 2008. Bank-specific, industry-specific and macroeconomic determinants of bank profitability. J. Int. Financial Markets Institutions Money, 18: 121-136.

Atikogullari, M., 2009. An analysis of the Northern Cyprus banking sector in the post-2001 period through the CAMELS approach. Int. Res. J. Finance Econ., 32: 212-229.

Berger, A.N., S.D. Bonime, D.M. Covitz and D. Hancock, 2000. Why are bank profits so persistent? The roles of product market competition, informational opacity and regional/macroeconomic shocks. J. Banking Finance, 24: 1203-1235.

Bikker, J.A. and H. Hu, 2002. Cyclical patterns in profits, provisioning and lending of banks and procyclicality of the new Basel capital requirements. BNL Quart. Rev., 221: 143-175.

Goddard, J.A., P. Molyneux and J.O. Wilson, 2004. Dynamics of growth and profitability in banking. J. Money Credit Banking, 36: 1069-1090.

Haron, S., 2004. Determinants of Islamic bank profitability. Global J. Finance Econ., 1: 11-33.

Khan, A.G., 2012. The relationship of capital structure decisions with firm performance: A study of the engineering sector of Pakistan. Int. J. Account. Financial Reporting, 2: 245-262.

Kosmidou, K., F. Pasiouras, M. Doumpos and C. Zopounidis, 2004. Foreign versus domestic bank's performance in the UK: A multicriteria approach. Comput. Manage. Sci., 1: 329-343.

Meslier, C., R. Tacneng and A. Tarazi, 2014. Is bank income diversification beneficial? Evidence from an emerging economy. J. Int. Financial Markets Institutions Money, 31: 97-126.

Sufian, F. and M.S. Habibullah, 2009. Bank specific and macroeconomic determinants of bank Profitability: Empirical evidence from the China banking sector. Front. Econ. China, 4: 274-291.

Yang, Y. and A. Chan, 2010. A hierarchical approach to measure service performance in the resort hotel's service encounters. J. Tourism Hospitality Culinary Arts, 2: 55-66.

Zeitun, R. and G.G. Tian, 2007. Capital structure and corporate performance: Evidence from Jordan. Aust. Account. Bus. Finance J., 1: 40-53. 